\title{
INTRODUKSI TEKNOLOGI TEPAT GUNA TEKNIK FILTRASI PADA PEMBUATAN MINYAK KELAPA TRADISIONAL (MINYAK JELENG) DI DESA GONDANG KECAMATAN GANGGA KABUPATEN LOMBOK UTARA
}

\author{
Murad $^{1}$, Sukmawaty ${ }^{1}$, Rahmat Sabani ${ }^{1}$ \\ ${ }^{1}$ Program Studi Teknik Pertanian, Fakultas Teknologi Pangan dan Agroindustri \\ Universitas Mataram \\ $\left.{ }^{*}\right)$ Korespondensi: muradfatepa@unram.ac.id
}

Diterima 1 Mei 2019 / Disetujui 23 Juni 2019

\begin{abstract}
ABSTRAK
Nusa Tenggara Barat (NTB) termasuk daerah penghasil buah kelapa yang potensial di Indonesia. Luas lahan produksi kelapa 59.387,09 ha dengan jumlah produksi sebesar $58.963,04$ ton (BPS, 2018). Sebagian buah kelapa keadaan utuh dikirim keluar daerah dan sebagian lagi dimanfaatkan oleh masyarakat setempat untuk pembuatan minyak kelapa tradisional. Dikatakan tradisionl, karena proses pembuatan minyak dilakukan dengan tahapan sederhana yaitu pembuatan santan, pemanasan santan dan pemisahan minyak. Tujuan kegiatan ini adalah pelatihan teknologi tepat guna teknik filtrasi pada pembuatan minyak kelapa tradisional skala home idustries di Desa Gondang Kecamatan Gangga Kabupaten Lombok Utara. Metode kegiatan menggunakan metode Pendidikan Orang Dewasa (POD) atau Androgogi dengan menekankan partisipasi aktif dari peserta, kerja kelompok dan demonstrasi penerapan TTG teknik filtrasi pada pembuatan minyak kelapa tradisional skala home idustries. Pelaksanaan pelatihan di Desa Gondang Kecamatan Gangga Kabupaten Lombok Utara. Mekanisme pelaksanaan pelatihan meliputi ; acara pembukaan, penyampaian materi gambaran umum tentang tanaman kelapa dan pemanfaatan tanaman kelapa, tentang teknik pengolahan minyak kelapa dan pengemasan, praktek teknik filtrasi atau penyaringan minyak kelapa tradisional dan teknik pengemasan. Pada pelatihan teknik filtrasi atau penyaringan minyak kelapa tradisional absorben yang digunakan adalah batu zeolit. Pemanfaatan zeolit ini memberikan nilai tambah yang cukup besar, dibandingkan jika dimanfaatkan hanya sebagai bahan pengganti batu bata atau batako. Hasil penyaringan minyak kelapa tradisional dengan menggunakan zeolit sebagai absorben memberikan hasil yang cukup maksimal serta meningkatkan mutu dan kualitas minyak kelapa tradisional. Mutu dan kualitas minyak kelapa tradisional yang dihasilkan dengan ciri-ciri sifat fisik, kimia dan organoleptic, seperti warna lebih jernih (tidak kotor atau keruh), kadar air rendah (menyebabkan daya simpan lebih lama) serta aroma dan rasa dapat dipertahankan sebagai khas minyak kelapa tradisional. Kegiatan filtrasi minyak kelapa dilakukan dengan satu set alat filtrasi dengan urutan filter sebagai berikut: mulai dari ujung paling bawah dipasangkan kertas saring, selanjutnya kapas, kain kasa, batu zeolit, dan terakhir kawat saring.
\end{abstract}

Kata Kunci: kelapa, minyak kelapa, TTG, teknik filtrasi 


\section{PENDAHULUAN}

Kelapa (coco) merupakan komoditas yang secara tradisional telah dimanfaatkan oleh masyarakat Indonesia. Hal ini dapat dilihat, bahwa semua bagian tanaman kelapa dapat dimanfaatkan. Nusa Tenggara Barat (NTB) termasuk daerah penghasil buah kelapa yang potensial di Indonesia. Dengan luas areal 59.387,09 ha, dihasilkan buah kelapa yang dapat mencapai jumlah 58.963,04 ton (BPS, 2018). Sebagian buah kelapa tersebut (dalam keadaan utuh) dikirim keluar daerah yaitu ke pulau Jawa, dan sebagian lagi dimanfaatkan oleh masyarakat setempat untuk pembuatan minyak kelapa tradisional (pengolahan minyak kelapa dengan metode basah/wet method). Dikatakan tradisionl, karena proses pembuatan minyak dilakukan dengan tahapan sederhana yaitu pembuatan santan, pemanasan santan dan pemisahan minyak.

Dari berbagai jenis tanaman industri, kelapa merupakan jenis yang serbaguna. Buah kelapa yang terdiri atas sabut, tempurung, daging buah dan air kelapa tidak ada yang terbuang dan dapat dibuat untuk menghasilkan produk industri. Daging buah kelapa dapat diolah menjadi santan yang dapat dijadikan bahan pengganti susu atau dijadikan minyak. Minyak hasil ekstrasi dapat digunakan untuk memasak dan membuat margarin, disamping itu dapat juga digunakan sebagai bahan bakar. Sisa dari ekstrasi minyak merupakan bahan untuk makanan ternak, sementara itu sabut kelapa dapat digunakan untuk membuat matras, peredam dan kerajinan tangan.

Di NTB khususnya pulau Lombok banyak terdapat pengolahan minyak kelapa tradisional oleh masyrakat. Masyarakat yang paling banyak mengolah minyak kelapa tradisional terletak di Kabupaten Lombok Barat, Lombok Timur, Lombok Tengah, Lombok Utara seperti di desa Gondang kecamatan Gangga dengan menyerap ratusan tenaga kerja (BPS, 2018). Akibat pengolahan tradisioanal maka minyak kelapa belum dianggap mampu bersaing dengan minyak sejenis dari kelapa sawit baik dari segi harga maupun kemasan produk. Keuntungan minyak kelapa adalah dapat dipakai berulang-ulang dengan kondisi lebih baik dibandingkan dengan minyak kelapa sawit yang mempunyai kecendrungan rusak bila dipakai berulang-ulang.

Aplikasi ipteks berupa teknologi tepat guna yang selama ini dilakukan oleh Perguruan Tinggi terhadap industri rumah tangga (home industries) pembuatan minyak kelapa tradisional lebih banyak dititik beratkan pada proses pembuatan minyak kelapa baik dari awal proses maupun sampai akhir (menjadi minyak). Beberapa teknologi tepat guna yang telah diaplikasikan diantaranyamesin pemarut kelapa, Alat pengaduk pembuatan santan, Alat pemeras santan atau pengepres santan, Pemisahan protein, air, dan minyak. Namun belum ada yang menerapkan teknologi tepat guna pasca pembuatan minyak kelapa, agar diperoleh minyak yang bermutu dan berkualitas serta memiliki daya simpan yang cukup tinggi.

Adapun permasalahan sangat penting yang harus dicari jalan pemecahannnya pada masyarakat industri kecil atau industri rumah tangga (home industries) pembuat minyak kelapa tradisional adalah masih tingginya kadar air yang terkandung, bila dibandingkan dengan minyak sawit yang ada dipasaran. Bila kadar air yang terkandung dalam minyak cukup besar akan mengakibatkan minyak tersebut cepat tengik karena terjadi proses oksidasi. Proses oksidasi tersebut juga dipengaruhi oleh tidak baiknya tutup kemasan yang digunakan yang mengakibatkan udara atmosfir menerobos masuk ke dalam minyak. Udara lembab yang terperangkap dalam minyak 
tersebut akan meningkatkan kadar air. Semakin tinggi kadar air yang terkandung dalam minyak, maka semakin cepat timbulnya bau tengik. Hal inilah yang menyebabkan keengganan konsumen untuk membeli minyak tersebut.

Sebagai alternatif untuk memecahkan permasalahan tersebut adalah dengan diaplikasikannya teknologi tepat guna teknik filtrasi dan penggunaan kemasan kedap udara. Dengan diaplikasikannya metode ini, akan-mampu meningkatkan mutu dan kualitas serta daya simpan minyak kelapa tradisional.

\section{METODE PELAKSANAAN}

Kegiatan ini dilakukan melalui pelatihan serta demonstrasi dengan menggunakan metode Pendidikan Orang Dewasa (POD) atau Androgogi dengan menekankan partisipasi aktif dari peserta (kelompok sasaran), kerja kelompok dan demonstrasi penerapan teknologi tepat guna teknik filtrasi pada skala home idustries pembuatan minyak kelapa tradisional.

Cakupan materi kegiatan Pelatihan sekurang-kurangnya meliputi:

1. Gambaran umum tentang tanaman kelapa dan pemanfaatan tanaman kelapa

2. Gambaran umum tentang teknik pengolahan minyak kelapa dan pengemasan

3. Praktek teknik filtrasi atau penyaringan minyak kelapa tradisional dan teknik pengemasan

Pelaksanaan evaluasi kegiatan ini dilakukan dengan melihat kelompokkelompok masyarakat pengolah kelapa menjadi minyak tradisional yang mampu menerapkan pengetahuan dan keterampilan yang telah diperoleh dari pelatihan dengan konsisten dan berkelanjutan di desa Gondang kecamatan Gangga kabupaten Lombok Utara.

\section{HASIL DAN PEMBAHASAN}

Di Nusa Tenggara Barat, khususnya di Desa Gondang Kecamatan Gangga Kabupaten Lombok Utara penanganan pasca panen kelapa masih minim dilakukan, hal ini disebabkan karena masih kurangnya pengetahuan masyarakat dalam penanganan pasca panen dan atau pengolahan kelapa. Sebagian besar produk kelapa dipasarkan dalam bentuk segar, ada sebagian kecil dari masyarakat yang melakukan pengolahan kelapa menjadi minyaktetapi masih dilakukan secara tradisional. Dengan demikian produk olahan kelapa seperti minyak yang dihasilkan memiliki mutu dan kualitas yang masih rendah.

Aplikasi ipteks berupa penerapan teknologi tepat guna teknik filtrasi pada skala home idustries pembuatan minyak kelapa tradisional yang selama ini dilakukan oleh Perguruan Tinggi terhadap industri rumah tangga (home industries) pada pengolahan tradisional lebih banyak dititik beratkan pada proses pembuatan baik dari awal proses sampai akhir proses menjadi produk jadi.

$$
\text { Adapun permasalahan sangat }
$$

penting yang harus dicari jalan pemecahannya di tingkat kelompok usaha rumah tanggapada pembuat minyak kelapa secara tradisional adalah minyak tersebut sangat cepat mengalami proses oksidasi (tengik) terutama tanpa pengemasan yang kedap udara. Hal inilah yang menyebabkan produk minyak kelapa tradisional tidak bisa tembus pasar menengah ke atas dikarenakan minyak kelapa tradisional memiliki mutu dan kualitas yang masih rendah serta daya simpan yang masih rendah pula. Padahal dari satu sisi bahwa minyak kelapa tradisional memiliki kelebihan diantaranya memiliki aroma yang khas dan bisa digunakan lebih dari satu kali.

Sebagai alternatif untuk memecahkan permasalahan tersebut 
adalah dengan diaplikasikannya teknologi tepat guna teknik filtrasi pada skala home idustries pembuatan minyak kelapa tradisional. Dengan diaplikasikannya metode ini, dapatmeningkatkan daya tahan produk (keawetan)serta dapat meningkatkan mutu dan kualitas produk minyak kelapa tradisional.

Dalam kegiatan ini, langkah awal yang dilakukan adalah menyiapkan segala kebutuhan untuk pelatihanaplikasi penerapan teknologi tepat guna teknik filtrasi pada skala home idustries pembuatan minyak kelapa tradisional.

Pelatihan ini dilaksanakan di Desa Gondang Kecamatan Gangga Kabupaten Lombok Utara. Alasan lokasi ini digunakan untuk pelatihan, karena sebagian besar masyarakatnya sebagai kelompok tani kelapa yang sudah dan sedang melakukan usaha pembuatan minyak kelapa tradisional.

\section{A. Kegiatan Survey}

Sebelum pelatihan terlebih dahulu dilakukan survei untuk mengidentifikasi kelompok masyarakat usaha rumah tangga yang beraktifitas dalam pembuatan minyak kelapa. Dari hasil identifikasi diperoleh kelompok industri rumah tangga pengolahan minyak kelapa tradisional dengan nama kelompok "ITA AMOR COCO" beranggotakan 20 (dua puluh) orang dengan alamat Dusun Amor Desa Gondang Kecamatan Gangga Kabupaten Lombok Utara.

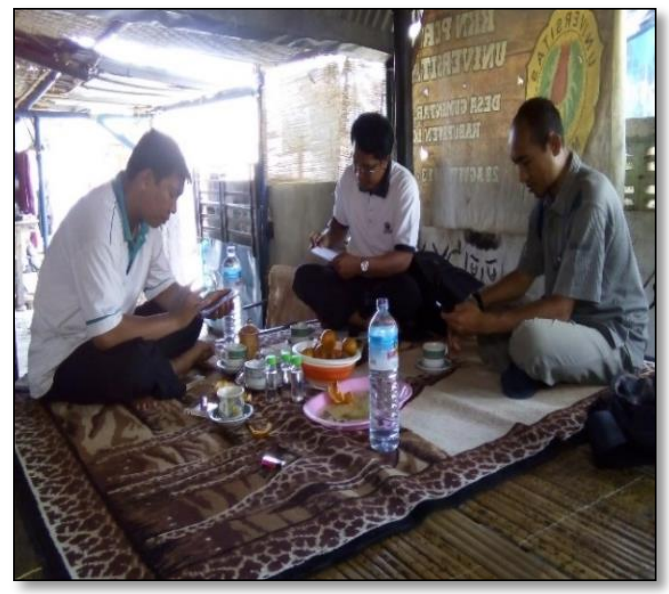

Gambar 1. Foto Kegiatan Survei

\section{B. Kegiatan Pelatihan di Tingkat Kelompok}

Pelaksanaan pelatihan aplikasi penerapan teknologi tepat guna teknik filtrasi pada skala home idustries pembuatan minyak kelapa tradisional di Desa Gondang Kecamatan Gangga Kabupaten Lombok Utara, terlebih dahulu masing-masing anggota kelompok menyiapkan bahn-bahan dan peralatan yang diperlukan. Bahan-bahan dan peralatan yang diperlukan diantaranya ; buah kelapa, parang atau linggis, alat pemarut kelapa, bak plastik, baskom, ember plastik, alat pemeras santan kelapa, saringan santan, wajan, kompor, pengaduk, alat filter minyak kelapa, batu zeolit, kapas, kertas saring atau kain saring dan kemasan.

Mekanisme pelaksanaan pelatihan meliputi; acara pembukaan atau pengantar, penyampaian materi gambaran umum tentang tanaman kelapa dan teknologi pengolahan kelapa, materi gambaran umum tentang minyak kelapa dan pengolahannya, praktek pembuatan minyak kelapa tradisional serta teknik filtrasi minyak kelapa.

Kegiatan praktek pembuatan minyak kelapa tradisional dan teknik filtrasi meliputi ; persiapan bahan (kelapa) dan peralatan yang diperlukan. Kelapa terlebih dahulu dikupas sabut dan tempurungnya, 
kemudian dibelah dan diparut dengan menggunakan mesin pemarut kelapa. Hasil parutan kelapaditampung menggunakan bak plastik dan ditambahkan air dengan perbandingan 1:10 (1 liter cair, $10 \mathrm{~kg}$ kelapa parut). Selanjutnya dilakukan mengepresan yang dapat dilakukan dengan cara manual dan dapat dilakukan dengan menggunakan alat pres santan. Setelah proses pengepresan (pemisahan santan kelapa), selanjutnya ditempatkan pada bak plastik atau baskom dan didiamkan selama 3-12 jam atau disentrifuge agar lapisan santan bakal minyak terpisah. Bakal minyak santan kelapa selanjutnya dipanaskan dengan menggunakan wajan pada suhu $90^{\circ}$ sampai dengan $100^{\circ} \mathrm{C}$ kurang lebih 3-4 jam, tergantung kapasitas (sampai terbentuk minyak). Setelah diperoleh minyak kelapa yang dibuat secara tradisional sebelum dikemas, maka terlebih dahulu dilakukan penyaringan dengan penerapan teknologi tepat guna teknik filtrasi dengan menggunakan batu zeolit sebagai absorbernya. Kegiatan pelatiahan penerapan teknologi tepat guna teknik filtrasi pada skala home idustries pembuatan minyak kelapa tradisional di Desa Gondang Kecamatan Gangga Kabupaten Lombok Utara dapat dilihat pada Gambar berikut :

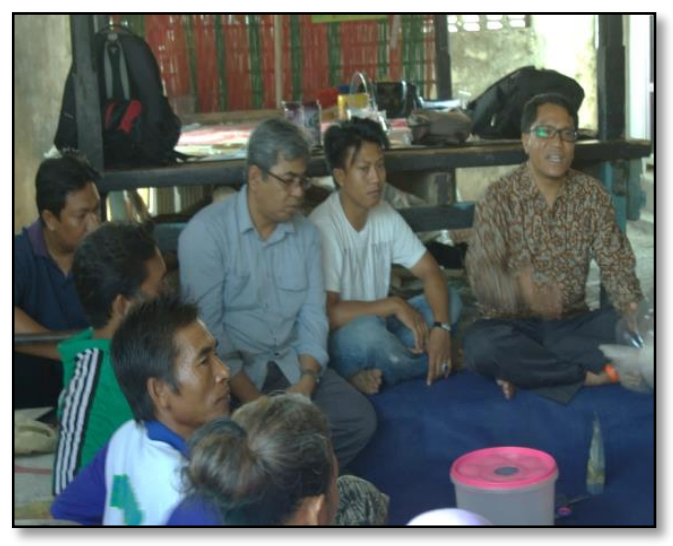

Gambar 2. Foto Acara Pembukaan dan Penyampaian Materi Pelatihan

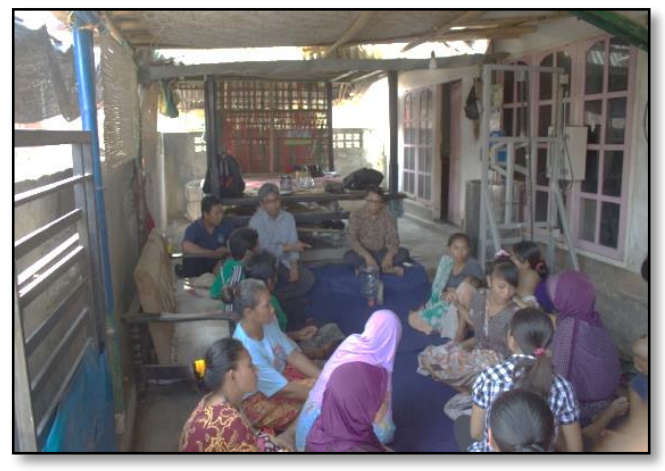

Gambar 3. Foto Peserta Pelatihan

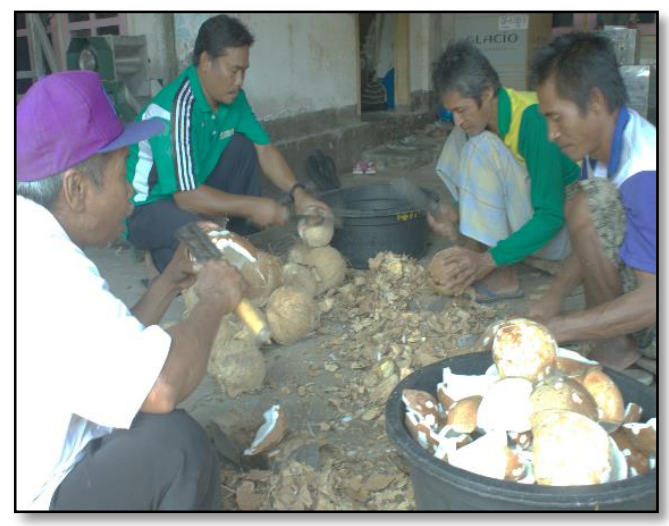

Gambar 4. Foto Proses Pengupasan Kelapa

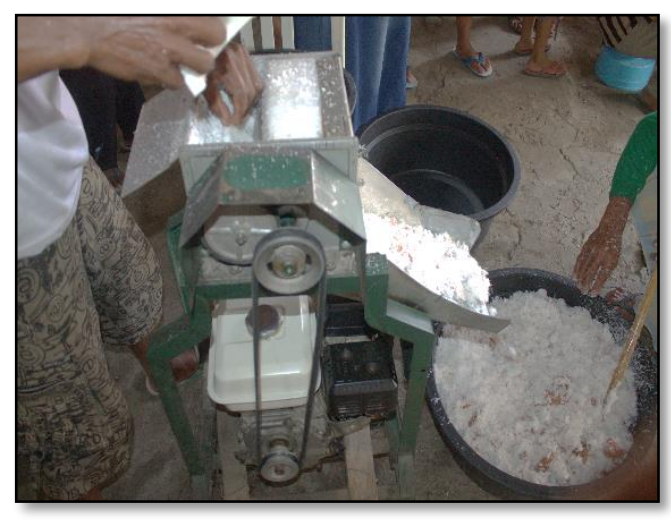

Gambar 5. Foto Proses Pemarutan Kelapa 


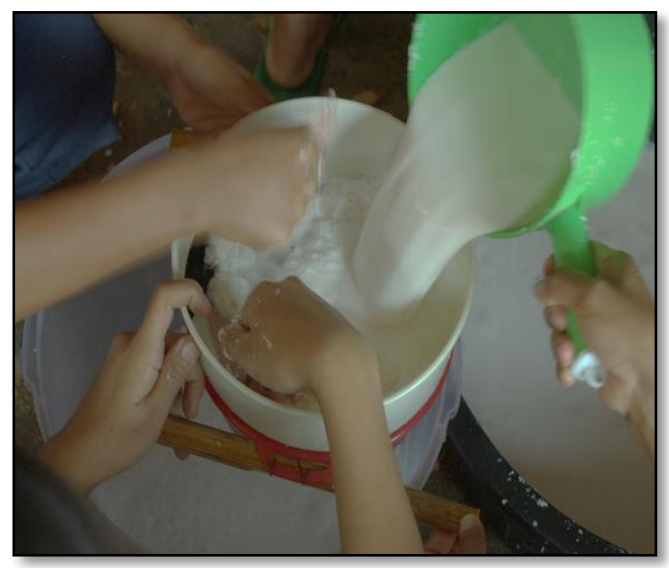

Gambar 6. Foto Proses Pemerasan atau Pengepresan dan Pengendapan Santan Kelapa

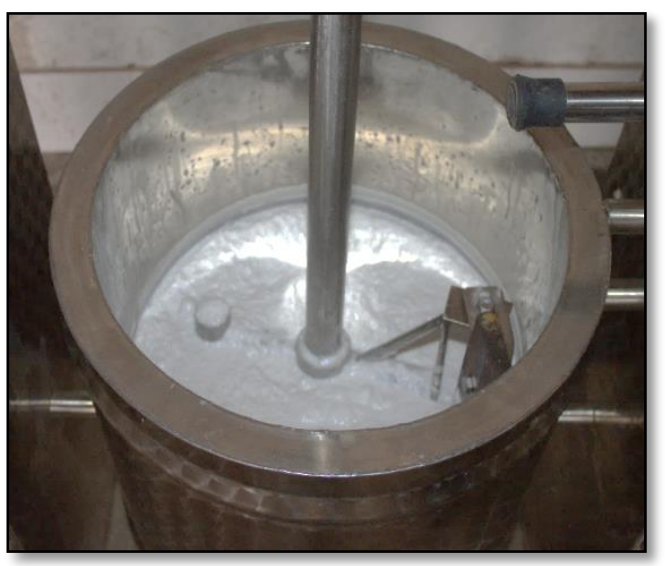

Gambar 7. Foto Proses Pemanasan Santan

\section{Kegiatan Teknik Filtrasi Minyak Kelapa Tradisional (Minyak Jeleng)}

Salah satu metode yang dianggap sederhana, ekonomis dan mudah untuk perbaikan kualitas minyak kelapa adalah dengan cara filtrasi atau adsorbsi. Adsorbsi adalah peristiwa penyerapan di permukaan oleh suatu adsorben atau daya serap dari zat penyerap yang terjadi pada permukaan. Keberhasilan proses adsorbsi ditentukan oleh pemilihan adsorben. Adsorben yang digunakan harus memenuhi kriteria yang dibutuhkan, diantaranya mempunyai daya serap yang besar terhadap solute, zat padat yang mempunyai luas permukaan yang besar, tidak larut dalam zat cair yang akan diadsorbsi, tidak beracun dan mudah didapat serta memiliki harga yang relatif murah (Syabanu dan Cahyaratri, 2010).

Pada pelatihan ini absorben yang digunakan adalah batu zeolit. Zeolit merupakan salah satu bahan alternatif yang dapat dipergunakan untuk bahan penjernih (bleaching agent) minyak kelapa, dimana potensi industri ini sangat besar. Pemanfaatan zeolit ini akan memberikan nilai tambah yang cukup besar, dibandingkan jika dimanfaatkan hanya sebagai bahan pengganti batu bata atau batako.

Prinsip kerja batu zeolit pada proses penyaringan minyak kelapa adalah setelah aktivasi akan terjadi penurunan kadar alumina sehingga nisbah silikat/alumina meningkat yang mengakibatkan peningkatkan porositas zeolit dan meningkatkan kemampuannya sebagai adsorben. Dengan demikian jika digunakan sebagai absorben pada proses penyaringan minyak kelapa tradisional akan memiliki kemampuan mengikat air atau menyerap air tinggi, sehingga kadar air pada minyak kelapa tradisional menjadi berkurang selama proses penyaringan.

Hasil penyaringan minyak kelapa tradisional dengan menggunakan zeolit sebagai absorben memberikan hasil yang cukup maksimal serta meningkatkan mutu dan kualitas minyak kelapa tradisional. Mutu dan kualitas minyak kelapa tradisional yang dihasilkan dengan ciri-ciri sifat fisik, kimia dan organoleftik seperti : warna lebih jernih (tidak kotor atau keruh), kadar air rendah (menyebabkan daya simpan lebih lama) serta aroma dan rasa dapat dipertahankan sebagai khas minyak kelapa tradisional. Kegiatan filtrasi minyak kelapa dilakukan dengan satu set alat filtrasi dengan urutan filter sebagai berikut : mulai dari ujung paling bawah dipasangkan kertas saring, selanjutnya kapas, kain kasa, batu zeolit, dan terakhir kawat saring. Kegiatan proses filtrasi 
minyak kelapa tradisional serta hasilnya dapat dilihat pada Gambar berikut ini:

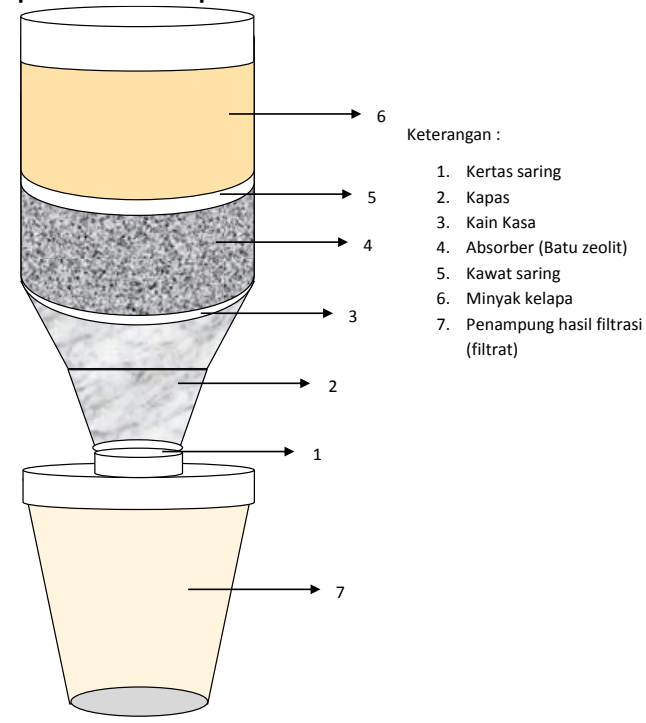

Gambar 94. Foto Desain Penyaring Minyak Kelapa

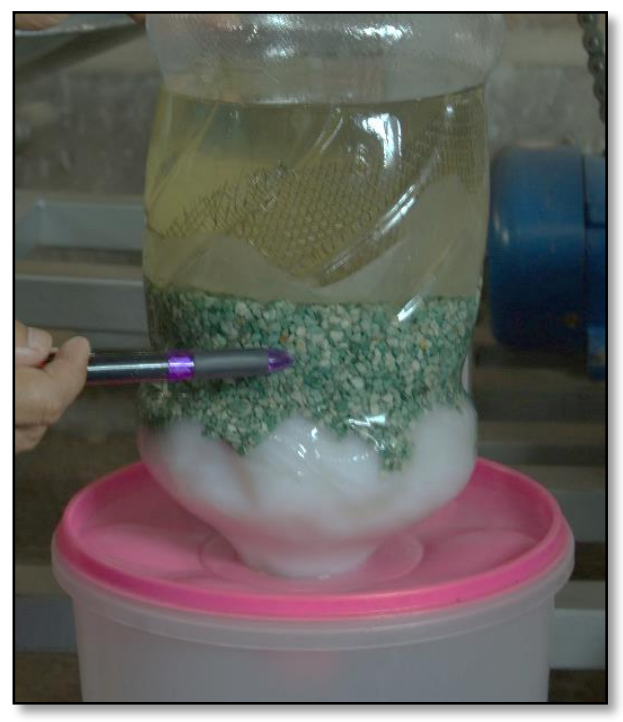

Gambar 50. Foto Proses Penyaringan Minyak Kelapa Tradisional

Produk minyak kelapa tradisional (minyak jeleng) yang diolah dengan penerapan teknologi tepat guna teknik filtrasi menggunakan batu zeolit sebagai absorber. Berdasarkan hasil pengamatan menunjukkan bahwa produk minyak jeleng kelapa memiliki kelebihan diantaranya : memiliki daya simpan lebih lama yaitu \pm 5 6 bulan dengan pengemasan kedap udara, memiliki aroma, bau dan cita rasa yang khas bisa dipertahankan selama penyimpanan serta tidak cepat tengik, memiliki warna dan tingkat kejernihan yang lebih tinggi. Dengan demikian produk minyak jeleng kelapa yang diolah dengan penerapan teknologi tepat guna (teknik filtrasi) memiliki nilai ekonomi yang cukup tinggi dan memiliki peluang pasar kelas menengah dan kelas atas.

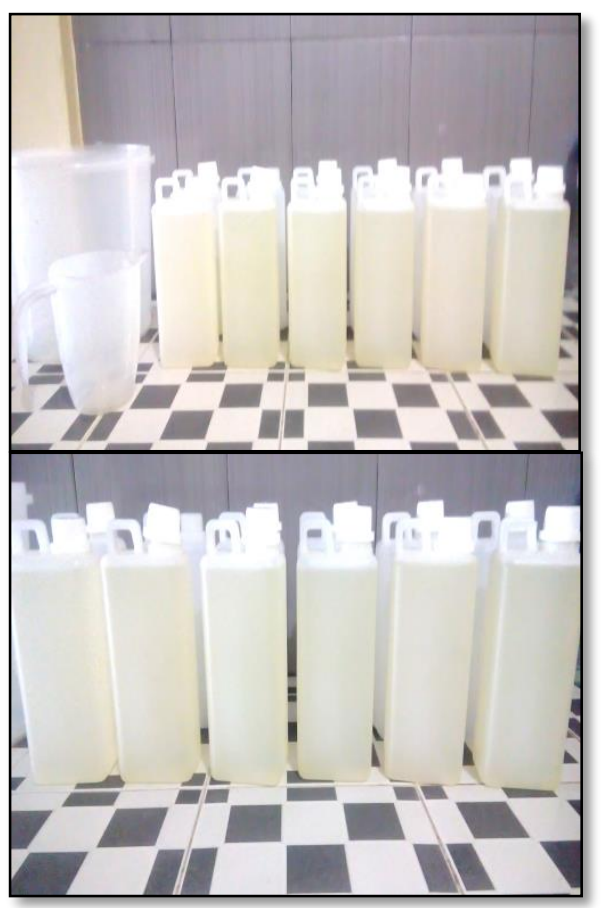

Gambar 11. Foto Produk Kemasan Minyak Kelapa Tradisional

\section{Kegiatan Monitoring dan Evaluasi}

Setelah pelatihan dilaksanakan maka dilakukan monitoring kegiatan kelompok dalam pembuatan minyak kelapa tradisional (minyak jeleng) yang dilaksanakan 1 (satu) bulan setelah pelatihan. Kegiatan monitoring ini bertujuan untuk melihat hasil pelatihan yang sudah dilaksanakan dan sejauh mana masyarakat atau kelompok industri rumah tangga (home industries) mengaplikasikan ilmu dan keterampilan yang telah diperoleh dari kegiatan pelatihan serta mengevaluasi tingkat keberhasilan masyarakat dalam penerapan teknologi 
tepat guna teknik filtrasi pada pembuatan minyak kelapa tradisional.

Dari hasil monitoring dapat disimpulkan bahwa masyarakat setempat sangat antosias dengan melihat hasil olahannya dengan penerapan teknologi tepat guna teknik filtrasi pada pembuatan minyak kelapa tradisional. Antosiasme masyarakat dibuktikan dengan aktifitas masyarakat dalam pembuatan minyak kelapa tradisional, masing-masing kelompok membuat dan menghasilkan minyak kelapa tradisional sebanyak 10 liter per hari. Beberapa kendala yang dihadapi oleh masyarakat adalah wadah dan fasilitas yang masih terbatas, maka perlu dilakukan pembinaan lebih lanjut mengenai optimalisasi produksi melalui pengawalan dan pendampingan kelompok dalam memproduksi minyak kelapa tradisional (minyak jeleng).

\section{KESIMPULAN DAN SARAN}

\section{A. Kesimpulan}

1. Kegiatan pelatihan ini lebih ditekankan pada pemahaman penerapan teknologi tepat guna teknik filtrasi pada skala home idustries pembuatan minyak kelapa tradisional.

2. Dengan penerapan teknologi tepat guna teknik filtrasi pada pembuatan minyak kelapa tradisional, masyarakat sangat merasakan kelebihan jika dibandingkan dengan tanpa penerapan teknologi tepat guna teknik filtrasi.
3. Kelebihan yang diperoleh dengan penerapan teknologi tepat guna teknik filtrasi pada skala home idustries pembuatan minyak kelapa tradisional adalah mutu dan kualitasnya lebih tinggi dengan bau yang tidak cepat tengik, aroma dan rasa yang khas serta daya tahan yang lebih lama dengan daya simpan $\pm 5-6$ bulan.

\section{B. Saran}

Kendala yang dihadapi oleh kelompok adalah wadah dan fasilitas yang masih terbatas, maka perlu dilakukan pembinaan lebih lanjut mengenai optimalisasi produksi melalui pengawalan dan pendampingan kelompok dalam memproduksi minyak kelapa tradisional.

Diperlukan perhatian dan peran serta pemerintah dalam pembinaan kelompok masyarakat yang berkelanjutan.

\section{DAFTAR PUSTAKA}

BPS, 2018. Nusa Tenggara Barat dalam Angka. Badan Pusat Statistik. Nusa Tenggara Barat.

Syabanu, A dan Cahyaratri, F., 2010. Pemanfaatan Asam Sitrat sebagai Adsorben dalam Upaya Peningkatan Kualitas Minyak Goreng Bekas Melalui Proses Adsorbsi. Diakses melalui http://eprints.undip.ac.id. tanggal 20 April 2015. 